\begin{abstract}
Iranica
Abstracta Iranica Revue bibliographique pour le domaine irano-aryen

Volume 34-35-36 | 2017

Comptes rendus des publications de 2011-2013
\end{abstract}

\title{
Javier Álvarez-Mon. The Golden Griffin from Arjan
}

\section{Astrid Nunn}

\section{(2) OpenEdition}

\section{Journals}

Édition électronique

URL : http://journals.openedition.org/abstractairanica/41427

DOI : 10.4000/abstractairanica.41427

ISSN : 1961-960X

Éditeur :

CNRS (UMR 7528 Mondes iraniens et indiens), Éditions de l'IFRI

\section{Référence électronique}

Astrid Nunn, "Javier Álvarez-Mon. The Golden Griffin from Arjan », Abstracta Iranica [En ligne], Volume 34-35-36 | 2017, document 3, mis en ligne le 15 juillet 2016, consulté le 05 octobre 2020. URL : http:// journals.openedition.org/abstractairanica/41427 ; DOI : https://doi.org/10.4000/abstractairanica. 41427

Ce document a été généré automatiquement le 5 octobre 2020.

Tous droits réservés 


\title{
Javier Álvarez-Mon. The Golden Griffin from Arjan
}

\author{
Astrid Nunn
}

\section{RÉFÉRENCE}

Javier Álvarez-Mon. « The Golden Griffin from Arjan », in : Javier Álvarez-Mon, Mark B. Garrison, eds., Elam and Persia. Winona Lake, Eisenbrauns, 2011, p. 299-373.

1 En 2010 paraissait la thèse de doctorat de l'A. sur une chambre funéraire découverte en 1982 et située à égale distance entre Suse et Persépolis (cf. Abs. Ir. 32-33, c.r. n²3). Un des objets les plus extraordinaires que contenait cette tombe est un anneau ouvert en or dont les ouvertures se terminent en palmettes. L'intérieur des palmettes est décoré de deux griffons dressés qui se font face. Le présent article tout en reprenant les informations fondamentales sur la tombe, ajoute des détails de fabrication sur cet anneau d'or composé de trois 3 pièces séparées. L'anneau est également comparé avec d'autres qui ont la même forme mais qui ne sont pas ornés (Choga Zambil/Čogaāzanbīl). Suit l'analyse iconographique des griffons en les comparant avec les griffons glaçurés et les sceaux de Choga Zambil/Čogaāzanbīl, avec des objets de Suse, des bronzes du Luristan, des sceaux néo-élamites et néo-assyriens et enfin avec les reliefs de Persépolis. L'A. note une affiliation à l'art assyrien et propose la date de 625 av. J.-C. pour cet anneau. Il. propose également la périodisation suivante dans le développement de l'art néo-élamite : la phase élamo-assyrienne, env. 653 à 630/626, une renaissance élamite, env. 630/626 à 585/575 et une période d'innovation, env. $585 / 575$ à 550/540. 


\section{AUTEURS}

\section{ASTRID NUNN}

Université de Munich 